\title{
THE EFFECT OF EDTA-SE WITH DIFFERENT CONCENTRATIONS ON PHOTOSYNTHESIS OF FRAGRANT RICE (ORYZA SATIVA L.)
}

\author{
LAI, R. F. ${ }^{1,2 \#}-$ ZHANG, T. T. ${ }^{1,2 \#}-$ GAO, Y. H. ${ }^{3 \#}-$ LU, R. H. ${ }^{1 \#}-$ LIU, Y. F. - ZHENG, A. X. ${ }^{1}-$ \\ ASHRAF, U. ${ }^{4}-$ FAN, P. S. ${ }^{5}-$ DU, B. ${ }^{1,2}-$ LUO, H. W. ${ }^{1,2}-$ TANG, X. R..$^{1,2 *}$ \\ ${ }^{I}$ Department of Crop Science and Technology, College of Agriculture, South China Agricultural \\ University, Guangzhou, 510642, PR China \\ ${ }^{2}$ Scientific Observing and Experimental Station of Crop Cultivation in South China, Ministry of \\ Agriculture, Guangzhou, 510642, PR China \\ ${ }^{3}$ College of Agriculture, South China Agricultural University, Guangzhou, 510642, PR China \\ ${ }^{4}$ Department of Botany, University of Education, Lahore, Faisalabad-Campus, 38000, \\ Punjab, Pakistan
}

${ }^{5}$ Hainan Key Laboratory for Sustainable Utilization of Tropical Bio-resources, Institute of Tropical Agriculture and Forestry, Hainan University, 570228, Haikou, China

${ }^{\#}$ These authors have contributed equally to this work.

*Corresponding author

e-mail: tangxr@scau.edu.cn

(Received $19^{\text {th }}$ Nov 2018; accepted $25^{\text {th }}$ Jan 2019)

\begin{abstract}
Selenium (Se), as an essential element, has its effects on the growth and development of plants. Present study aimed to assess Se mediated chlorophyll contents, net photosynthesis, biomass accumulation and activity of carbon metabolism enzymes. Three different levels of Ethylenediamine tetra acetic acid - chelating Se (EDTA-Se) at 10(E1), 30(E2) and 50(E3) $\mu \mathrm{mol} \mathrm{L}^{-1}$ were overhead applied at initial heading stage of two aromatic rice cultivars i.e., Xiangyaxiangzhan and Meixiangzhan2, the treatment without Se were served as control (CK). Results revealed that exogenous Se applications enhanced the chlorophyll content as well as net photosynthetic rate $(\mathrm{Pn})$, meanwhile, grain weight at maturity and the biomass accumulation during the filling had been remarkably improved. Furthermore, growth, yield and quality components were also improved by Se application. Hence, Se proved better for both rice cultivars whereas the E2 was the best treatment with the highest yield, biomass accumulation and net photosynthesis rate.
\end{abstract}

Keywords: selenium, rice, net photosynthetic rate, biomass accumulation, chlorophyll content

\section{Introduction}

Rice production is the cornerstone of Chinese food safety system. Recently, as the human populations swell across the world, the demand for rice has been increasing, while available cultivated land for it has been decreasing. The study of Krishnan et al. (2007) showed that it was possible there would be 10 billion people on the earth. In the coming decades, it would lead to increasing the demand for rice. Aromatic rice is a delicacy in rice and has always been the focus of the people because of its predominant tasty, captivating fragrance and other unique features. Despite aromatic rice has been fetching an extremely high price, interestingly, the demand for it keeps growing steadily (Mo et al., 2016). However, just like other rice cultivars, the yield of fragrant rice is affected by many uncertain factors such as 
climate condition and other environmental factor. For example, Mo et al. (2015) demonstrated that shading the aromatic rice plant during the grain filling stage could significantly reduce its yield. Further study on lead $(\mathrm{Pb})$ stress caused a huge loss in yield of fragrant rice (Ashraf et al., 2018). Meanwhile, a series of researches indicated that certain artificial regulation and application could improve the quality and yield of aromatic rice. Ren et al. (2017) found that fertilizer treatment and severe drought conditions applying separately not only improved the yield of aromatic rice significantly, but also enhanced the 2-acetyl-1pyrroline (2-AP), the key element of the fragrance of aromatic rice, content in the plant (Yajima et al., 1979). The investigation of Pan et al. (2017) also found that mechanized deep placement of nitrogen fertilizer elevated aromatic rice yield dramatically.

Multiple microelements are available to promote fragrant rice performance. Li et al. (2016) demonstrated that Manganese $(\mathrm{Mn})$ could regulate yield information of aromatic rice and enhanced 2-AP content in grains by improving the synthesis of proline and pyrroline-5carboxylic acid (P5C) (2-AP's precursors) as well as promoting activity of proline dehydrogenase (ProDH). The report of Mo et al. (2017) revealed that Silicon (Si) application had ability to improve the growth, yield, quality and 2-AP contents of fragrant rice because of the net photosynthetic $(\mathrm{Pn})$ rates, proline contents and activity of ProDH being enhanced.

Selenium (Se), as a significant element, plays an essential role for humans, animals and plants. An analysis (Gladyshev et al., 1999) of Se revealed that poor immune function, high risk of mortality, and cognitive decline had been associated with deficiency of Se while taking Se supplementation had improved the virus inhibitory effect and reduced the risk of catching an autoimmune thyroid disease. With the advance of research, Se was proven to be able to against toxic elements such as arsenic, antimony, mercury and copper (Srivastava et al., 2009; Gotsis, 1982). Moreover, the research of Wang et al. (2012) generated a selenium-enriched rice with high production and enough bioavailability by using selenite fertilization.

Photosynthesis, as an important physiological process in rice, affected rice growth and yield significantly (Zhong et al., 2019; Cao et al., 2018). Normally, the proportion of cop biomass which is directed towards the harvested part could decide the potential of rice yield. To date, there are few reports about fragrant rice photosynthesis and the effect of Se application on fragrant rice. Moreover, Ethylenediamine tetra acetic acid - chelating Se (EDTA-Se) is a new exiting form of selenium element. Hence, it has much room for investigation and based on the hypothesis that exogenous Se application in initial heading stage could enhance the rice photosynthetic characteristics during the filling stage, this study was conducted in Guangdong province (major rice producing province in South China) in order to study the effect of EDTA-Se on rice photosynthesis and dry matter accumulation during the filling stage.

\section{Materials and methods}

\section{Plant materials and growing condition}

Two aromatic rice cultivars, Xiangyaxiangzhan and Meixiangzhan2, which are widely cultivated at South China, having 111-114 days of growth period were planted in late season at Experimental Research Farm, College of Agriculture, South China Agricultural University,

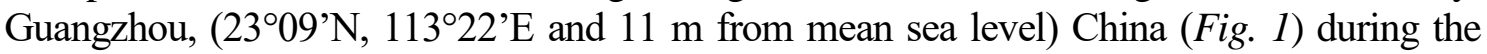
July and November in 2017. This region has subtropical-monsoonal type of climate with mean annual air temperatures of $26.6^{\circ} \mathrm{C}$, mean annual maximum and minimum air temperatures of $14^{\circ} \mathrm{C}$ in November and $37^{\circ} \mathrm{C}$ in August, respectively. Before sowing, the seeds were soaked in water for $24 \mathrm{~h}$, germinated in manual climatic box for the next $24 \mathrm{~h}$, 
dried in the shade. Then the germinated seeds were sown in PVC trays for nursery raising. 20day-old seedlings were transplanted to the field at the planting distance $(30 \mathrm{~cm} \times 12 \mathrm{~cm})$. The experimental soil was sandy loam with of $25.65 \%$ organic matter content, $1.360 \%$ total $\mathrm{N}$, $0.956 \%$ total $\mathrm{P}$, and $17.460 \%$ total $\mathrm{K}$.

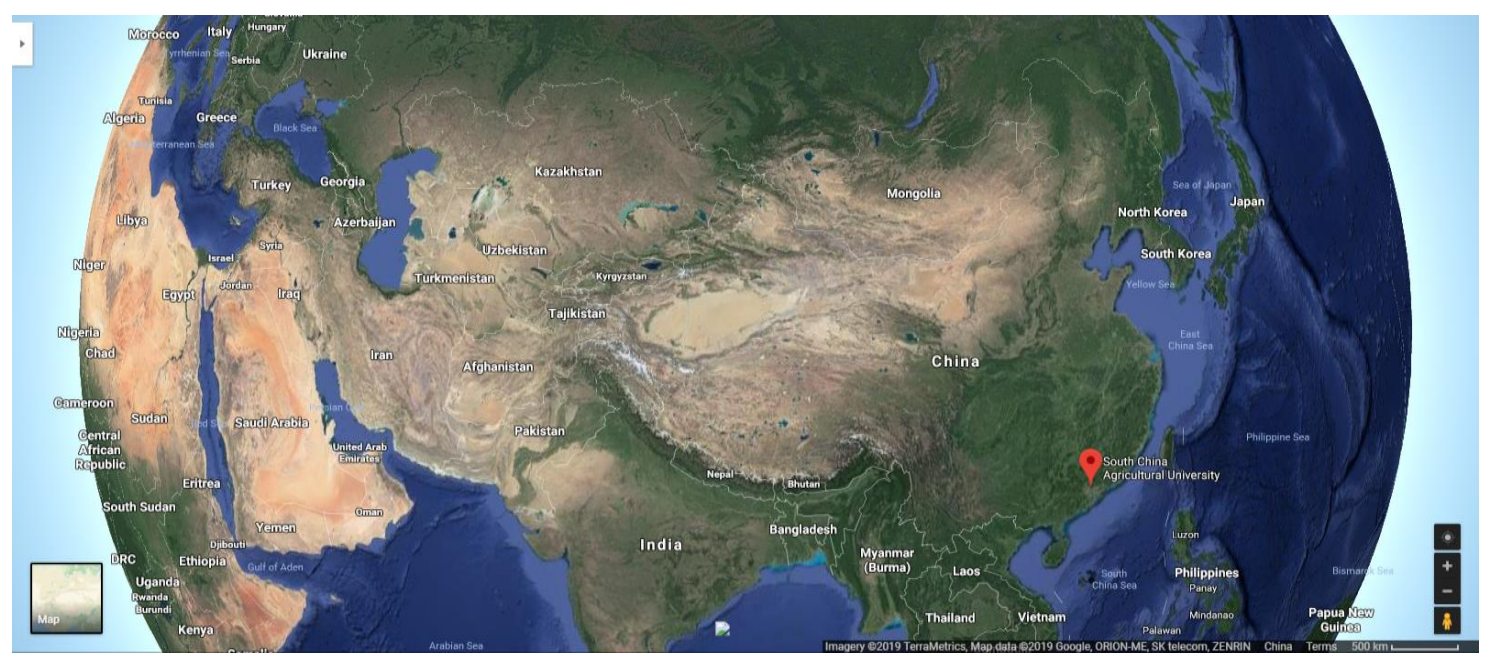

Figure 1. The location of the experimental site

\section{Treatments descriptions}

Experimental treatments were as described:

CK: Overhead sprinkle with double distilled water at initial heading stage of rice.

E1: Overhead sprinkle with EDTA- Se liquor $\left(10 \mu \mathrm{mol} \mathrm{L}^{-1}\right.$ pure selenite concentration) at initial heading stage.

E2: Overhead sprinkle with EDTA- Se liquor $\left(30 \mu \mathrm{mol} \mathrm{L}^{-1}\right.$ pure selenite concentration) at initial heading stage.

E3: Overhead sprinkle with EDTA- Se liquor $\left(50 \mu \mathrm{mol} \mathrm{L}^{-1}\right.$ pure selenite concentration) at initial heading stage.

\section{Plant sampling and determination of biomass accumulation}

At heading stage and maturity stage, the rice plants were harvested from six unit sampling areas $\left(1 \mathrm{~m}^{2}\right)$ in each plot. The leaves, stem-sheaths and grains were separated from the plants and dried under the condition of $80{ }^{\circ} \mathrm{C}$ respectively in order to get the estimation of dry matter. The thirty fresh flag leaves were separated and collected from the rice plants at the 15th day after heading stage, washed with double distilled water and stored under the condition of $-80^{\circ} \mathrm{C}$ for the sake of chlorophyll analysis.

Biomass accumulation during filling stage (BADF) was calculated as: $\mathrm{BADF}=$ Total dry weight at heading stage per hill - total dry weight at maturity per hill.

\section{Determination of photosynthesis}

Portable photosynthesis system (LI-6400, LI-COR, USA) was used to determine net photosynthetic rate at 09:00-10:30 a.m. according to the standard method (Pan et al., 2015). The photosynthesis was measured on 15 th day after the heading stage. 


\section{Estimation of chlorophyll contents}

The contents of total chlorophyll (total $\mathrm{Chl}$ ), chlorophyll a (Chl a) and chlorophyll b (Chl b) were determined by the methods of Anjum (2016). Grinding leaf sample (about $0.1 \mathrm{~g}$ ) was placed in $15 \mathrm{ml}$ centrifuge tube along with $95 \%$ absolute ethyl alcohol $(10 \mathrm{ml})$ and then kept at dark condition until the color of sample transformed turn into white. Then with the help of UV-visible spectrophotometer, Chl a, Chl b and total Chl contents were estimated at $645 \mathrm{~nm}, 652 \mathrm{~nm}$ and $663 \mathrm{~nm}$.

\section{Determination of yield and yield related traits}

At maturity stage, the rice grains were harvested from seven unit sampling area $\left(1 \mathrm{~m}^{2}\right)$ in each plot and then threshed by machine. The harvested grains were sun-dried and weighted in order to determinate the grain yield. Twenty hills of rice from different locations in each plot were sampled for estimate the average effective panicles number per hill. Then, three hills representative plants were taken for estimation of the yield related traits.

The economic coefficient (EC) was calculated as: $\mathrm{EC}=$ grain weight / whole plant weight.

\section{Statistical analysis}

Data were analyzed using statistical software 'Statistix 8.1' (Analytical Software, Tallahassee, FL, USA) while differences amongst means were separated by using least significant difference (LSD) test at 5\% probability level. Graphical representation was conducted via Sigma Plot 14.0 (Systat Software Inc., California, USA).

\section{Results}

\section{Chlorophyll contents}

Exogenous Se applications affected chlorophyll contents at filling stage significantly (Fig. 2). For Xiangyaxiangzhan, compared with $\mathrm{CK}$, all Se treatments markedly increased the contents of both total chlorophyll and chlorophyll a (except E3) while chlorophyll b content of E2 was 1.32-fold higher than CK. For Meixiangzhan2, the highest total chlorophyll, chlorophyll a and chlorophyll b were all recorded in E2 while the chlorophyll contents under E1, E2 and E3 treatments were all higher than CK respectively.

\section{Net photosynthetic rate}

As shown in Figure 3, net photosynthesis varied with different Se applications in both rice cultivars. The $\mathrm{E} 1$ treatment had highest value of net photosynthetic rate while there was no distinct difference between E1 and E2. The trend of net photosynthetic rate was recorded as: E1 > E2 > E3 > CK for both Xiangyaxiangzhan and Meixiangzhan2.

\section{Dry matter accumulation}

Different Se applications affected the dry matter accumulation during the filling stage of fragrant rice (Table 1). For Xiangyaxiangzhan, E2 treatment significantly increased the weight of stem and leaf as well as total aboveground weight when the 
specimen had been taken in both heading stage and maturity. Only E1 and E2 treatments improved the biomass accumulation significantly. For Meixiangzhan2, E2 remarkably improved grain weight at maturity and the biomass accumulation during the filling stage. All Se applications enhanced the total aboveground weight at maturity.
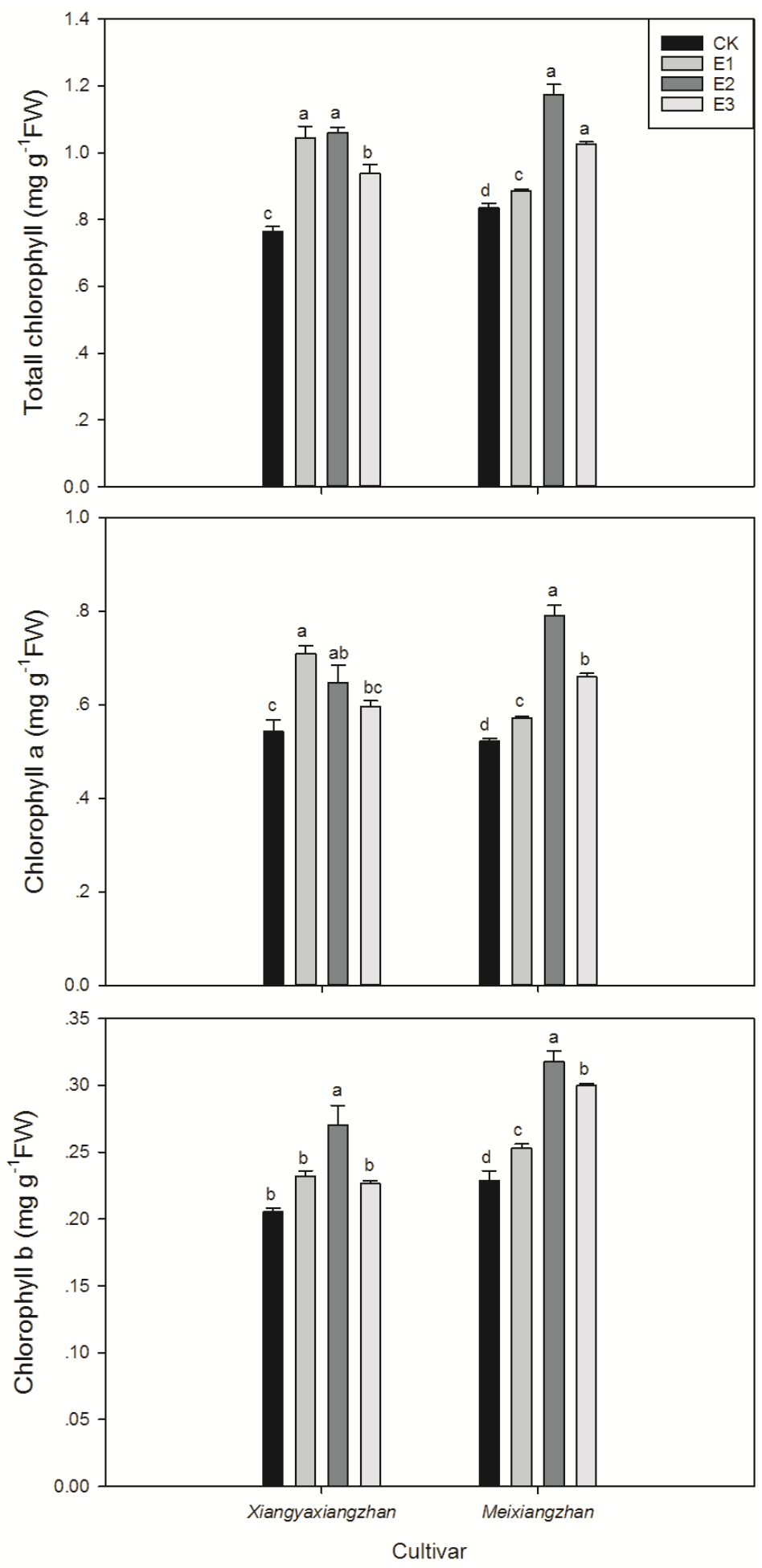

Figure 2. Effect of EDTA-Se on chlorophyll content. Means sharing a common letter do not differ significantly at $(P<0.05)$ according to least significant difference $(L S D)$ test for both the seasons. The same as below 


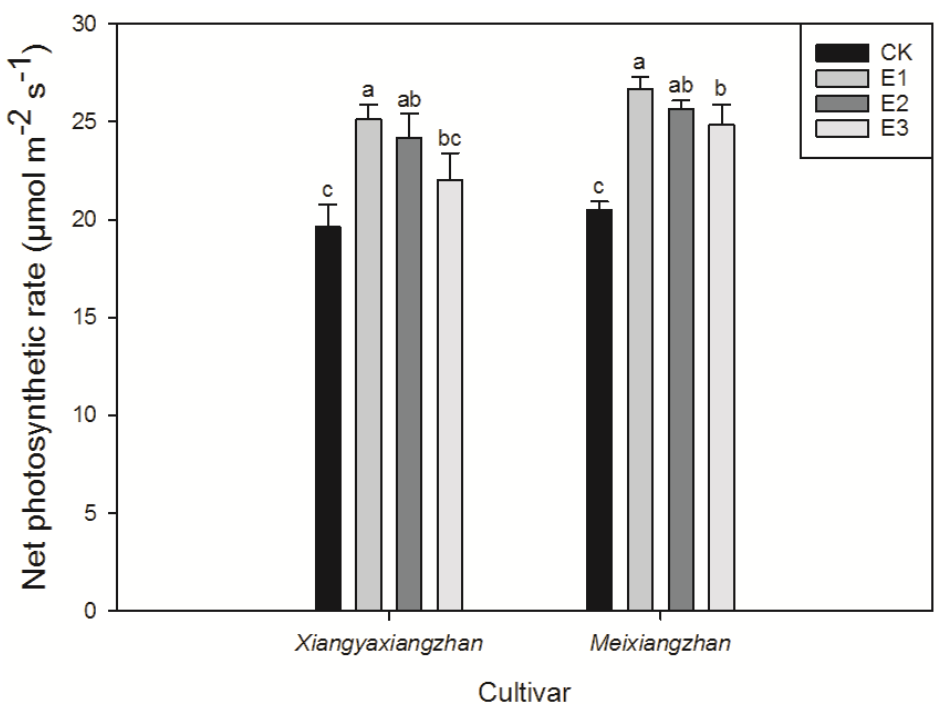

Figure 3. Effect of EDTA-Se on net photosynthetic rate

Table 1. Effect of EDTA-Se on dry matter accumulation during the filling stage

\begin{tabular}{|c|c|c|c|c|c|c|c|c|c|}
\hline \multirow[b]{2}{*}{ Treatments } & \multicolumn{4}{|c|}{ Heading stage } & \multicolumn{4}{|c|}{ Maturity } & \multirow[b]{2}{*}{$\begin{array}{l}\text { BDAF } \\
\left(\mathbf{g ~ m}^{-2}\right)\end{array}$} \\
\hline & $\begin{array}{c}\text { Stem } \\
\text { weight } \\
\left(\mathrm{g} \mathrm{m}^{-2}\right)\end{array}$ & $\begin{array}{c}\text { Leaf } \\
\text { weight } \\
\left(\mathrm{g} \mathrm{m}^{-2}\right)\end{array}$ & $\begin{array}{c}\text { Grain } \\
\text { weight } \\
\left(\mathrm{g} \mathrm{m}^{-2}\right)\end{array}$ & $\begin{array}{c}\text { Total } \\
\text { aboveground } \\
\text { weight } \\
\left(\mathrm{g} \mathrm{m}^{-2}\right) \\
\end{array}$ & $\begin{array}{c}\text { Stem } \\
\text { weight } \\
\left(\mathrm{g} \mathrm{m}^{-2}\right)\end{array}$ & $\begin{array}{c}\text { Leaf } \\
\text { weight } \\
\left(\mathrm{g} \mathrm{m}^{-2}\right)\end{array}$ & $\begin{array}{c}\text { Grain } \\
\text { weight } \\
\left(\mathrm{g} \mathrm{m}^{-2}\right)\end{array}$ & $\begin{array}{c}\begin{array}{c}\text { Total } \\
\text { aboveground } \\
\text { biomass } \\
\left(\mathrm{g} \mathrm{m}^{-2}\right)\end{array} \\
\end{array}$ & \\
\hline Xiangyaxiangzhan & & & & & & & & & \\
\hline $\mathrm{CK}$ & $610.67 \mathrm{c}$ & $223.49 b$ & $110.03 a$ & $944.00 \mathrm{~b}$ & $453.0 \mathrm{a}$ & $117.16 \mathrm{~b}$ & $464.55 b$ & $1035.12 \mathrm{~b}$ & $91.05 \mathrm{bc}$ \\
\hline E1 & $624.67 \mathrm{~b}$ & $240.40 \mathrm{ab}$ & $114.18 \mathrm{a}$ & $979.23 \mathrm{ab}$ & $459.67 \mathrm{a}$ & $125.37 \mathrm{ab}$ & $507.53 \mathrm{ab}$ & $1092.52 \mathrm{ab}$ & $113.53 b$ \\
\hline E2 & $639.67 \mathrm{a}$ & $253.33 \mathrm{a}$ & $109.05 \mathrm{a}$ & $1002.31 \mathrm{a}$ & $468.67 \mathrm{a}$ & $134.09 \mathrm{a}$ & $572.57 \mathrm{a}$ & $1175.20 \mathrm{a}$ & $173.23 \mathrm{a}$ \\
\hline E3 & $621.67 \mathrm{bc}$ & $231.00 \mathrm{ab}$ & $111.67 \mathrm{a}$ & $964.30 \mathrm{ab}$ & $455.00 \mathrm{a}$ & $124.16 \mathrm{ab}$ & $468.98 \mathrm{~b}$ & $1048.30 \mathrm{~b}$ & $83.98 \mathrm{c}$ \\
\hline Meixiangzhan 2 & & & & & & & & & \\
\hline $\mathrm{CK}$ & $602.58 \mathrm{~b}$ & $218.06 \mathrm{c}$ & $81.33 \mathrm{a}$ & $901.91 \mathrm{~b}$ & $420.06 \mathrm{a}$ & $150.39 \mathrm{c}$ & $601.53 \mathrm{~b}$ & $1171.90 \mathrm{c}$ & $269.95 b$ \\
\hline E1 & $617.00 \mathrm{ab}$ & $238.33 \mathrm{ab}$ & $85.00 \mathrm{a}$ & $940.33 a$ & $430.01 \mathrm{a}$ & $160.33 b$ & $632.89 \mathrm{~b}$ & $1223.21 b$ & $282.89 \mathrm{ab}$ \\
\hline E2 & $637.05 \mathrm{a}$ & $255.48 \mathrm{a}$ & $84.67 \mathrm{a}$ & $977.00 \mathrm{a}$ & $435.20 \mathrm{a}$ & $171.67 \mathrm{a}$ & $680.43 a$ & $1287.10 \mathrm{a}$ & $310.10 \mathrm{a}$ \\
\hline E3 & $628.12 \mathrm{a}$ & $235.17 b c$ & $79.67 \mathrm{a}$ & $943.08 \mathrm{a}$ & $429.19 a$ & $156.60 \mathrm{bc}$ & $630.15 b$ & $1215.80 \mathrm{~b}$ & $272.82 \mathrm{~b}$ \\
\hline
\end{tabular}

\section{Yield and its traits}

Overall, foliar applications of EDTA-Se at initial heading stage can increase grain yield of Xiangyaxiangzhan and Meixiangzhan2 (Table 2). For Xiangyaxiangzhan, E1, E2 and E3 had significant higher yield than CK, which were 4.20, 4.33, 4.21 and $4.00 \mathrm{t} \mathrm{ha}^{-1}$, respectively. For Meixiangzhan2, there was no remarkable difference among $\mathrm{CK}, \mathrm{E} 1, \mathrm{E} 2$ and E3 in panicle number, grain per panicle and filling percentage while both E1 and E3 increasing grain weight significantly and the highest yield was also recorded in E2.

\section{Correlation analysis}

As shown in Table 3, yield of fragrant rice had significant correlation with grain per panicle, biomass accumulation during filling stage and net photosynthetic rate. There exited a positive correlation between 1000-grain weight and biomass accumulation at 
filling stage. Furthermore, net photosynthetic rate had positive correlation with grain per panicle, biomass accumulation during the filling stage and total chlorophyll contents.

Table 2. Effect of EDTA-Se on fragrant rice yield and it traits

\begin{tabular}{|c|c|c|c|c|c|}
\hline Treatments & Panicle number $\left(\mathbf{m}^{-1}\right)$ & Grain per panicle & $\begin{array}{c}\text { Grain filling } \\
\text { percentage }(\%)\end{array}$ & $\begin{array}{l}\text { 1000-grain } \\
\text { weight (g) }\end{array}$ & Yield $\left(\mathrm{kg} \mathrm{m}^{-2}\right)$ \\
\hline \multicolumn{6}{|l|}{ Xiangyaxiangzhan } \\
\hline CK & $236.81 \pm 9.06 \mathrm{a}$ & $112.39 \pm 5.72 b$ & $81.72 \pm 4.32 \mathrm{a}$ & $18.54 \pm 0.19 \mathrm{a}$ & $0.40 \pm 0.01 \mathrm{c}$ \\
\hline E1 & $257.46 \pm 12.78 \mathrm{a}$ & $113.97 \pm 4.62 b$ & $83.72 \pm 2.16 \mathrm{a}$ & $18.28 \pm 0.32 \mathrm{a}$ & $0.42 \pm 0.01 \mathrm{~b}$ \\
\hline E2 & $230.27 \pm 14.47 \mathrm{a}$ & $148.27 \pm 15.21 \mathrm{a}$ & $81.32 \pm 3.82 \mathrm{a}$ & $18.94 \pm 0.34 \mathrm{a}$ & $0.43 \pm 0.02 \mathrm{a}$ \\
\hline E3 & $259.36 \pm 9.88 \mathrm{a}$ & $124.71 \pm 12.41 \mathrm{ab}$ & $79.73 \pm 4.74 a$ & $17.46 \pm 0.28 \mathrm{a}$ & $0.42 \pm 0.01 \mathrm{~b}$ \\
\hline \multicolumn{6}{|l|}{ Meixiangzhan2 } \\
\hline $\mathrm{CK}$ & $214.36 \pm 18.48 \mathrm{a}$ & $178.81 \pm 4.44 \mathrm{a}$ & $72.65 \pm 1.47 \mathrm{a}$ & $18.04 \pm 0.60 \mathrm{~b}$ & $0.51 \pm 0.01 \mathrm{~b}$ \\
\hline E1 & $218.06 \pm 12.10 \mathrm{a}$ & $177.12 \pm 5.06 \mathrm{a}$ & $78.76 \pm 0.64 a$ & $19.11 \pm 0.55 \mathrm{a}$ & $0.52 \pm 0.01 \mathrm{~b}$ \\
\hline E2 & $218.43 \pm 10.87 a$ & $177.36 \pm 13.73 a$ & $80.93 \pm 4.64 a$ & $18.65 \pm 0.39 \mathrm{ab}$ & $0.55 \pm 0.01 \mathrm{a}$ \\
\hline E3 & $229.89 \pm 16.06 a$ & $177.79 \pm 6.09 \mathrm{a}$ & $80.50 \pm 2.27 \mathrm{a}$ & $19.27 \pm 0.16 \mathrm{a}$ & $0.52 \pm 0.01 \mathrm{~b}$ \\
\hline
\end{tabular}

Table 3. Relationship among yield, yield compounds, biomass accumulation, photosynthesis and chlorophyll contents

\begin{tabular}{|c|c|c|c|c|c|c|c|}
\hline Parameters & Yield & $\begin{array}{c}\text { 1000-grain } \\
\text { weight }\end{array}$ & $\begin{array}{l}\text { Panicle } \\
\text { number }\end{array}$ & $\begin{array}{c}\text { Grain filling } \\
\text { percentage } \\
(\%)\end{array}$ & $\begin{array}{l}\text { Grain per } \\
\text { panicle }\end{array}$ & \begin{tabular}{|c|} 
Biomass \\
accumulation \\
during filling \\
stage \\
\end{tabular} & $\begin{array}{c}\text { Total } \\
\text { chlorophyl } \\
\text { content }\end{array}$ \\
\hline 1000-grain weight & 0.1438 & & & & & & \\
\hline Panicle number & -0.2360 & $0.3089 *$ & & & & & \\
\hline Grain filling percentage (\%) & -0.0654 & -0.2402 & -0.1826 & & & & \\
\hline Grain per panicle & $0.7787 * *$ & -0.1666 & $-0.7047 * *$ & -0.0937 & & & \\
\hline $\begin{array}{l}\text { Biomass accumulation during } \\
\text { filling stage }\end{array}$ & $0.8111 * *$ & $0.3900 * *$ & -0.2750 & -0.2566 & $0.6138 * *$ & & \\
\hline Total chlorophyll content & 0.2441 & -0.1594 & $-0.2847 *$ & $0.5343 * *$ & $0.2908 *$ & 0.0330 & \\
\hline Net photosynthetic rate & $0.4075^{* *}$ & 0.1801 & -0.1806 & 0.2475 & $0.3418^{*}$ & $0.3043 *$ & $0.6146^{*}$ \\
\hline
\end{tabular}

Significant correlations at $* \mathrm{P}<0.05$ and $* * \mathrm{P}<0.01$

\section{Discussion}

Photosynthesis plays an important role in rice growth and yield information (Zhong et al., 2017). Mitchell and Sheehy (2010) had already explained the relationship between photosynthesis and rice yield, this discovery also proposed the view of supercharging rice photosynthesis to increase yield. Our study evidenced the contributions of photosynthesis to fragrant rice yield by showing the significant positive correlation between yield and net photosynthesis rate at filling stage.

Photosynthesis is a complicated phenomenon in plants and is affected by a variety of factors. A previous study already discussed the relationship between the leaf photosynthetic capacity and leaf nitrogen while reviewing the factors which are limiting the photosynthesis under different growth environments (Mae, 1997). Study of Krishna et al. (2016) showed that cytokinin has ability to delay dark-induced senescence in rice by maintaining the chlorophyll cycle and photosynthetic complexes. There were also certain researches about the effects of metallic and non-metallic elements on the crop photosynthesis. The investigation of Sultanalkeda and Itoh (1999) indicated that $\mathrm{NaCl}$ salinity decreased the photosynthesis at the reproductive phase by closing the stomatal 
and reducing transpiration rate, leaf water content and biochemical constituents. For example, Chen et al. (2011) demonstrated that Silicon fertilizer could improve plant water status, photosynthesis and mineral nutrient absorption and alleviate the damage to rice plants caused by drought stress. In our study, we discovered that the net photosynthetic rate of fragrant rice at filling stage was enhanced significantly due to exogenous Se application. It might because the Se treatments increased the chlorophyll contents where absorbing and converting light energy in photosynthesis process. It was also strongly corroborated by the investigation of Wu et al. (2000) which revealed that the electron transfer rate of chloroplast increased with low Se concentration while high concentration of selenium leads to electron transfer rate decreased in chloroplast.

Furthermore, the production of rice photosynthesis is carbohydrate and the biomass accumulation of rice plants mostly depends on the net photosynthetic rate in whole growth period. The sucrose is not only the main form of the production of photosynthesis, but also the major transport form for photosynthetic carbon assimilates. The transport rate directly affected the development of library organs and was one of the important factors limiting the further increase of crop yield (Slewinski et al., 2009). Normally, the accumulation of sucrose in leaves is controlled by synthase and decomposition enzyme related to the activity of key enzymes of sucrose metabolism including SPS, SS and sucrose invertase. SPS catalyzes sucrose synthesis reaction whilst SS had the duality of synthesizing and decomposing sucrose (Baxter et al., 2003; Tobias et al., 2008; Miswar et al., 2008). For example, SS mainly catalyzes sucrose synthesis in leaves; however, in grains it catalyzes sucrose degradation. Present study observed that the dry matter accumulation of aromatic rice during the filling stage was improved because of Se treatments. In this study we considered that was the result of the enhancement of net photosynthetic rate.

Normally, the carbohydrate assimilation is the primary source of rice growth while reserving a complementary source for grain filling in rice (Dingkuhn and Gal, 1996). In this study, we observed that yield had remarkable positive correlation with dry matter weight accumulation during the filling stage. This result agreed with the investigation of Dingkuhn et al. (1990) in which study they demonstrated that about 40 to $45 \%$ of panicle dry matter come from measured canopy photosynthesis while 55 to $60 \%$ might be the translocation. Another study (Dingkuhn et al., 1990) also revealed that canopy photosynthesis provided $58 \%$ and $74 \%$ for panicle weight at maturity in direct-seeded and transplanted rice, respectively. Present study evidenced that EDTA-Se treatments improved dry matter accumulation during filling stage. Hence, we discovered that $\mathrm{Se}$ could be used to increase it because it could improve photosynthesis and finally increase yield.

\section{Conclusion}

As a plant growth regulator, $10-50 \mu \mathrm{mol} \mathrm{L}-1$ EDTA-Se concentration could increase the rice photosynthesis at filling stage and thus improved the dry matter accumulation and grain yield. Furthermore, the EDTA-Se applications enhanced the chlorophyll content and activities of SPS and SS and it might be the reason of Se treatments improving rice photosynthesis. For revealing the mechanism of how EDTA-Se affects rice physiology, much work should be done at molecular and physiological level. 
Acknowledgements. This study was supported by National Natural Science Foundation of China (31271646), Student's Platform for Innovation and Entrepreneurship Training Program (201810564029), National Key R\&D Program of China (2016YFD0700301), the World Bank Loan Agricultural Pollution Control Project in Guangdong (0724-1510A08N3684), the Technology System of Modern Agricultural Industry in Guangdong (2017LM1098) and Special Funds for Scientific and Technological Innovation and Cultivation of University Students Guangdong (pdjh2019a0075). The authors declare no conflicts of interest.

\section{REFERENCES}

[1] Anjum, S. A. (2016): Chromium toxicity induced alterations in growth, photosynthesis, gas exchange attributes and yield formation in maize. - Pakistan Journal of Agricultural Sciences 53: 751-757.

[2] Ashraf, U., Hussain, S., Akbar, N., Anjum, S. A., Hassan, W., Tang, X. (2018): Water management regimes alter $\mathrm{Pb}$ uptake and translocation in fragrant rice. - Ecotoxicology and Environmental Safety 149: 128-134.

[3] Baxter, C. J., Foyer, C. H., Turner, J., Rolfe, S. A., Quick, W. P. (2003): Elevated sucrose-hosphate synthase activity in transgenic tobacco sustains photosynthesis in older leaves and alters development. - Journal of Experimental Botany 54: 1813-20.

[4] Cao, X., Zhong, C., Zhu, C., Zhang, J., Zhu, L., Wu, L., Jin, Q. (2018): Variability of leaf photosynthetic characteristics in rice and its relationship with resistance to water stress under different nitrogen nutrition regimes. - Physiologia Plantarum. https://doi.org/10.1111/ppl.12909.

[5] Chen, W., Yao, X., Cai, K., Chen, J. (2011): Silicon alleviates drought stress of rice plants by improving plant water status, photosynthesis and mineral nutrient absorption. Biological Trace Element Research 142: 67-76.

[6] Dingkuhn, M., Gal, P. Y. L. (1996): Effect of drainage date on yield and dry matter partitioning in irrigated rice. - Field Crops Research 46: 117-126.

[7] Dingkuhn, M., Schnier, H. F., Datta, S. K. D., Wijangco, E., Dörffling, K. (1990a): Diurnal and developmental changes in canopy gas exchange in relation to growth in transplanted and direct-seeded flooded rice. - Aust. J. Plant Physiol 17: 119-134.

[8] Dingkuhn, M., Schnier, H. F., De Datta, S. K., Dörffling, K., Javellana, C., Pamplona, R. (1990b): Nitrogen fertilization of direct-seeded flooded vs. transplanted rice: II. Interactions among canopy properties. - Crop Science 30: 1284-1292.

[9] Gladyshev, V. N., Martín-Romero, F. J., Xu, X. M., Kumaraswamy, E., Carlson, B. A., Hatfield, D. L., Lee, B. J. (1999): Molecular biology of selenium and its role in cancer, AIDS and other human diseases. - Recent Res. Dev. Biochem. 1: 145-167.

[10] Gotsis, O, (1982): Combined effects of selenium/mercury and selenium/copper on the cell population of the alga Dunaliella minuta. - Marine Biology 71: 217-222.

[11] Krishna, T. S., Madhusmita, P., Saivishnupriya, K., Nirosha, P., Sarla, N., Rajeshwari, R. (2016): Cytokinin delays dark-induced senescence in rice by maintaining the chlorophyll cycle and photosynthetic complexes. - Journal of Experimental Botany 67: 1839-1851.

[12] Krishnan, P., Swain, D. K., Bhaskar, B. C., Nayak, S. K., Dash, R. N. (2007): Impact of elevated CO 2 and temperature on rice yield and methods of adaptation as evaluated by crop simulation studies. - Agriculture Ecosystems \& Environment 122: 233-242.

[13] Li, M., Ashraf, U., Tian, H., Mo, Z., Pan, S., Anjum, S. A., Duan, M., Tang, X. (2016): Manganese-induced regulations in growth, yield formation, quality characters, rice aroma and enzyme involved in 2-acetyl-1-pyrroline biosynthesis in fragrant rice. - Plant Physiology and Biochemistry 103: 167-175.

[14] Mae, T, (1997): Physiological nitrogen efficiency in rice: nitrogen utilization, photosynthesis, and yield potential. - Plant \& Soil 196: 201-210. 
[15] Miswar, M., Sugiharto, B., Soedarsono, J., Moeljapawiro, S. (2008): Transformasi gen sucrose phosphate synthase (SoSPS1) menggunakan Agrobacterium tumefaciens untuk meningkatkan sintesis sukrosa pada tanaman tebu (Saccharum officinarum L.). - Journal of Biological Researches 12: 137-143.

[16] Mitchell, P. L., Sheehy, J. E. (2010): Supercharging rice photosynthesis to increase yield. - New Phytologist 171: 688-693.

[17] Mo, Z., Li, W., Pan, S., Fitzgerald, T. L., Xiao, F., Tang, Y., Wang, Y., Duan, M., Tian, H., Tang, X. (2015): Shading during the grain filling period increases 2-acetyl-1pyrroline content in fragrant rice. - Rice 8. DOI: 10.1186/s12284-015-0040-y.

[18] Mo, Z., Huang, J., Xiao, D., Ashraf, U., Duan, M., Pan, S., Tian, H., Xiao, L., Zhong, K., Tang, X. (2016): Supplementation of 2-Ap, Zn and La improves 2-Acetyl-1-Pyrroline concentrations in detached aromatic rice panicles in vitro. - Plos One 11: e0149523.

[19] Mo, Z., Lei, S., Ashraf, U., Khan, I., Li, Y., Pan, S., Duan, M., Tian, H., Tang, X. (2017): Silicon fertilization modulates 2-acetyl-1-pyrroline content, yield formation and grain quality of aromatic rice. - Journal of Cereal Science 75: 17-24.

[20] Pan, S. G., Wen, X. C., Zhao-Wen, M. O., Duan, M. Y., Dong, H. R., Huang, G. X., Tian, H., Tang, X. R. (2015): Effects of nitrogen application and shading on yields and some physiological characteristics in different rice genotypes. - Chinese Journal of Rice Science 29(2): 141-149.

[21] Pan, S., Wen, X., Wang, Z., Ashraf, U., Tian, H., Duan, M., Mo, Z., Fan, P., Tang, X. (2017): Benefits of mechanized deep placement of nitrogen fertilizer in direct-seeded rice in South China. - Field Crops Research 203: 139-149.

[22] Ren, Y., Ashraf, U., He, L. X., Mo, Z. W., Wang, F., Wan, X. C., Kong, H., Ran, X. L., Tang, X. R. (2017): Irrigation and nitrogen management practices affect grain yield and 2-acetyl-1-pyrroline content in aromatic rice. - Applied Ecology and Environmental Research 15: 1447-1460.

[23] Slewinski, T. L., Meeley, R., Braun, D. M. (2009): Sucrose transporter1 functions in phloem loading in maize leaves. - Plant Signaling \& Behavior 60: 881-892.

[24] Srivastava, M., Ma, L. Q., Rathinasabapathi, B., Srivastava, P. (2009): Effects of selenium on arsenic uptake in arsenic hyperaccumulator Pteris vittata L. - Bioresource Technology 100: 1115.

[25] Sultana, N., Ikeda, T., Itoh, R. (1999): Effect of $\mathrm{NaCl}$ salinity on photosynthesis and dry matter accumulation in developing rice grains. - Environmental \& Experimental Botany 43: 181-183.

[26] Tobias, D. J., Hirose, T., Ishimaru, K., Ishige, T., Ohkawa, Y., Kano Murakami, Y., Matsuoka, M., Ohsugi, R. (2008): Elevated sucrose-phosphate synthase activity in source leaves of potato [Solanum tuberosum] plants transformed with the maize [Zea mays] SPS gene. - Plant Production Science 2: 92-99.

[27] Wang, Y. D., Wang, X., Wong, Y. S. (2012): Proteomics analysis reveals multiple regulatory mechanisms in response to selenium in rice. - Journal of Proteomics 75: 18491866.

[28] Wu, Y. Y., Lu, X. Y., Peng, Z. K., Luo, Z. M. (2000): Effect of Se on physiological and biochemical characters of paddy rice. - Scientia Agricultura Sinica 33(1): 100-103.

[29] Yajima, I., Yanai, T., Nakamura, M., Sakakibara, H., Hayashi, K. (1979): Volatile flavor components of cooked Kaorimai (scented rice, Oryza sativa japonica). - Journal of the Agricultural Chemical Society of Japan 43: 2425-2429.

[30] Zhong, C., Cao, X., Hu, J., Zhu, L., Zhang, J., Huang, J., Jin, Q. (2017): Nitrogen metabolism in adaptation of photosynthesis to water stress in rice grown under different nitrogen levels. - Frontiers in Plant Science 8: 1079.

[31] Zhong, C., Bai, Z., Zhu, L., Zhang, J., Zhu, C., Huang, J., Jin, Q., Cao, X. (2019): Nitrogen-mediated alleviation of photosynthetic inhibition under moderate water deficit stress in rice (Oryza sativa L.). - Environmental and Experimental Botany 157: 269-282. 


\section{APPENDIX}

\section{Photos of the experiment}
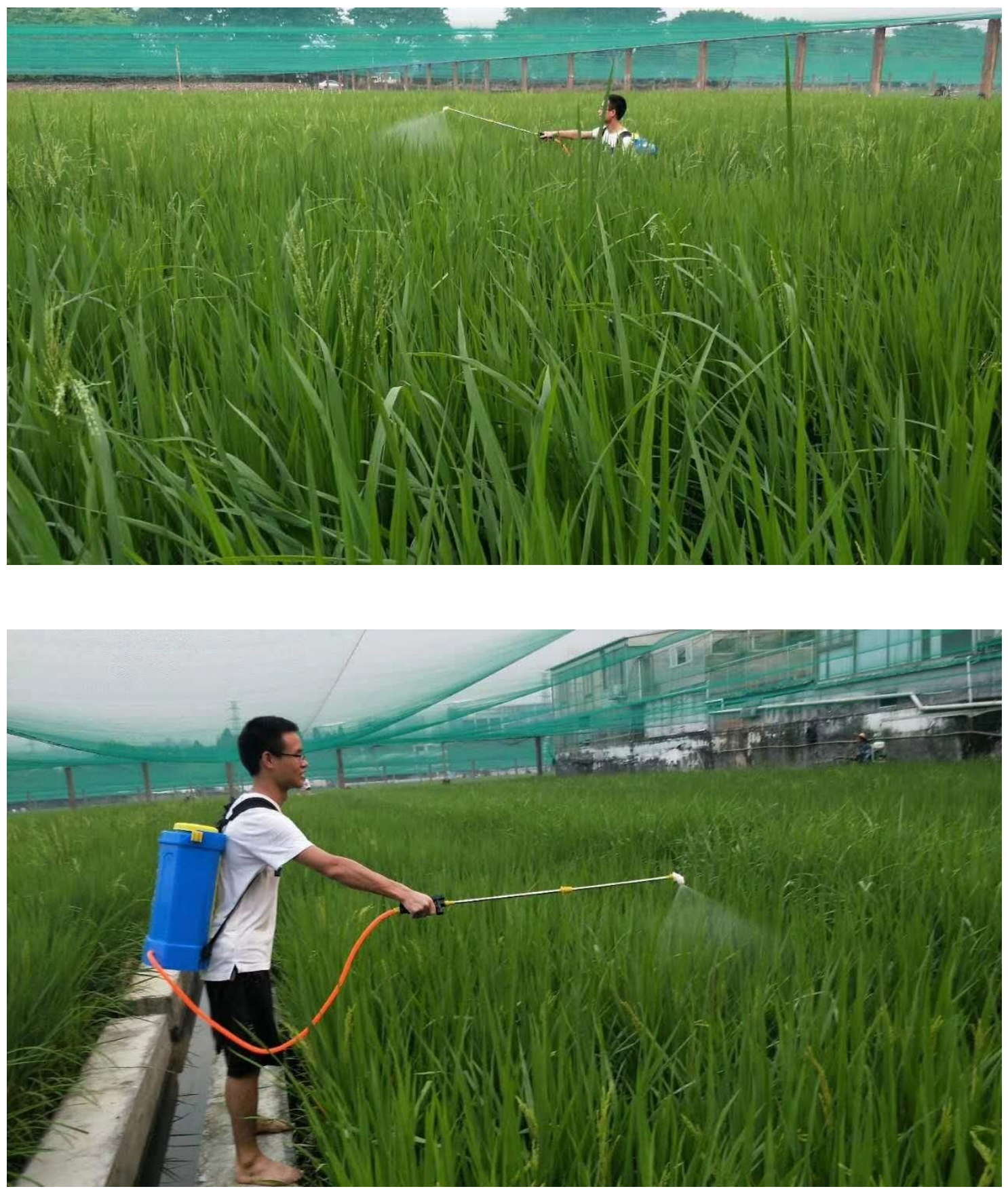

APPLIED ECOLOGY AND ENVIRONMENTAL RESEARCH 17(2):3293-3303.

http://www.aloki.hu • ISSN 15891623 (Print) • ISSN 17850037 (Online)

DOI: http://dx.doi.org/10.15666/aeer/1702_32933303

(c) 2019, ALÖKI Kft., Budapest, Hungary 